were suffering from thirst. They had covered a total distance of $460 \mathrm{~km}$. (287 miles) in $57 \mathrm{hr}$.

Nordenskiöld, who knew their capabilities, saw no reason to doubt their account, but found on his return to Sweden that few would believe that such a distance could be covered in so short a time. Therefore a race was arranged over a course of 23 Swedish miles (from Purkijaur to Kvikkjokk in Norrbottens län and back). The route was chosen to resemble Greenland ice-cap conditions. Out of thirty entries only ten completed the course, seven of whom were Lapps. Pavva Lars Tuorda covered the distance of $220 \mathrm{~km}$. (137 miles) in $21 \mathrm{hr}$., 22 min., a considerably faster speed than on the Greenland ice-cap.

There is no doubt that the experience gained from Nordenskiöld's expedition prompted Peary and especially Nansen to adopt skis as a standard item in their equipment. Apart from this, the ski race and its results caused great interest not only in Sweden but throughout the world. Considerable attention was focused on ski-ing as a sport and ski races soon became common events. Lapps figured prominently in these races, especially in the earlier years, and Lapps represented Sweden at several international meetings.

\title{
THE HUMAN ECOLOGY OF GREENLAND.
}

[Summarised from "Greenland-an experiment in human ecology". By M. J. Dunbar. Commerce Journal, March 1047, pp. 69-109.]

The Polar Record, Nos. 33-34, January-July 1947, contains a review of the Danish work of administration in East Greenland. An interesting comparison is afforded by Professor Dunbar's consideration of the Greenlanders of the west coast from the ecological point of view, that is to say from the study of the human population of West Greenland in relation to the fundamental biological, physical and other factors not only of its environment, but also inherent in itself.

The factors, or variables, from which the pattern of Greenland's economy and development is woven, are these:

1. The population, its growth and distribution.

2. Hydrographic changes in West Greenland.

3. The decline of the sea-mammals in West Greenland.

4. The growth of the West Greenland fishery.

5. The development of sheep-farming in the southwest.

6. The cryolite mine and the cryolite market.

7. Miscellaneous resources.

8. The native mind and its education.

9. Health.

10. The policy of the Danish administration.

11. Scientific exploration.

12. Greenland's strategic position.

This approach to a problem in the sphere of colonial administration, and of development and welfare, is most valuable and instructive. This satisfying treatment of the Danish West Greenland colonial problem is, however, possible only because it is still relatively simple, the chief factors being only a dozen in number and still capable of being disentangled one from another. Although the ecological approach would lead, because of the greater complexity, to less 
satisfying results elsewhere, it could, none the less, be very usefully applied even to many tropical territories still in the colonial phase of development.

The problems which now face the Greenlanders, it should be said at once, are in no way the result of lack of benevolence or effort on the part of the Danish administration. The Greenlanders provide an arctic example of problems arising largely from a rapid increase of population following a partial removal, or control, of some of the pre-existing causes of mortality.

Professor Dunbar gives such an admirably simple, yet profound analysis of the Greenland problem, that it is worth quoting a large section of his "Summary and conclusion":

The economy of Greenland has changed drastically during the past thirty years. Unrestricted slaughter of the migrant seals in the Newfoundland and Jan Mayen areas has seriously cut down the seal populations which visit Greenland in the spring and summer. Changing hydrographic conditions in west Greenland have driven arctic members of the marine fauna northward, and replaced them with Atlantic immigrants, the most important of which are codfish and the Atlantic halibut. The population of the country has in consequence turned from a hunting economy to a mixed livelihood of hunting and fishing. In the southwest a sheep-farming industry is well established and is growing. There is an ever-present possibility that the hydrographic and climatic cycle may have reached its warm peak and may swing back to more arctic conditions. The problem therefore is to use the cod fishery to the limit while it exists and at the same time (1) to prepare the Greenlanders to be able to use ocean-going fishing vessels for use in more southern waters if necessary, and (2) to negotiate for the control and re-establishment of the migrant seals on an international basis. Nothing short of this will ensure the future livelihood of the Greenland population, which is growing fast and has now passed the 20,000 mark.

Greenland's economy, at least during the present years of transition and development, operates on a very narrow margin. The deficit which is shown in some years is made up by the Government's 50 per cent interest in the cryolite mine at Ivigtut. The cryolite ore-body is not inexhaustible, and moreover the market for cryolite is not as sure today as it was before the invention of synthetic substitutes. The economy of Greenland must therefore, in the long run, reckon without the aid of this source of income.

For the full realization of Greenland's possibilities in fisheries and in sheep-farming, and in order to meet the increasing encroachments of the outside world, there must be considerable changes in the Greenlanders' education, which is still somewhat narrow and unrealistic. Another prerequisite to full development is an improvement of the health of the country. There is here a circular effect, in that for education, health and industry, capital outlays would be necessary which the administration is unwilling to make, probably because there would be an inevitably increased deficit which though temporary, would be politically undesirable.

The traditional policy of the Greenland Administration is one of exceedingly slow progress towards a condition in which the Greenlanders can look after themselves. This end lies a very long way in the future, but there has been a considerable development during the second world war, when the colony was administered from within, and when certain innovations forced upon the country proved to be of great permanent value. The Administration in Copenhagen requires some time to assimilate these changes and to appreciate the new outlook of the Greenlanders. Amongst the most important demands of the Greenlanders today are the establishment of responsible administration within Greenland and the reform and expansion of the educational system. 